University of Nebraska - Lincoln

DigitalCommons@University of Nebraska - Lincoln

USDA National Wildlife Research Center - Staff Publications
U.S. Department of Agriculture: Animal and Plant Health Inspection Service

2-6-2019

\title{
Invasive feral swine damage to globally imperiled steephead ravine habitats and influences from changes in population control effort, climate, and land use
}

\author{
Richard M. Engeman \\ APHIS, s_r100@yahoo.com \\ Erica Laine \\ Eglin AFB Natural Resources \\ John Allen \\ USDA/APHIS/Wildlife Services \\ Jeremy Preston \\ Eglin AFB Natural Resources \\ William Pizzolato \\ Eglin AFB Natural Resources
}

See next page for additional authors

Follow this and additional works at: https://digitalcommons.unl.edu/icwdm_usdanwrc

Part of the Life Sciences Commons

Engeman, Richard M.; Laine, Erica; Allen, John; Preston, Jeremy; Pizzolato, William; Williams, Brett; Kreider, Amanda Stevens; and Teague, Dennis, "Invasive feral swine damage to globally imperiled steephead ravine habitats and influences from changes in population control effort, climate, and land use" (2019). USDA National Wildlife Research Center - Staff Publications. 2234.

https://digitalcommons.unl.edu/icwdm_usdanwrc/2234

This Article is brought to you for free and open access by the U.S. Department of Agriculture: Animal and Plant Health Inspection Service at DigitalCommons@University of Nebraska - Lincoln. It has been accepted for inclusion in USDA National Wildlife Research Center - Staff Publications by an authorized administrator of DigitalCommons@University of Nebraska - Lincoln. 


\section{Authors}

Richard M. Engeman, Erica Laine, John Allen, Jeremy Preston, William Pizzolato, Brett Williams, Amanda Stevens Kreider, and Dennis Teague 


\title{
Invasive feral swine damage to globally imperiled steephead ravine habitats and influences from changes in population control effort, climate, and land use
}

\author{
Richard M. Engeman, et al. [full author details at the end of the article]
}

Received: 24 August 2018 / Revised: 21 January 2019 / Accepted: 6 February 2019 /

Published online: 15 February 2019

(c) This is a U.S. government work and its text is not subject to copyright protection in the United States; however, its text may be subject to foreign copyright protection 2019

\begin{abstract}
Steephead ravines are unusual geological features primarily occurring in Florida's panhandle, a biodiversity hotspot. The unique habitats formed by steepheads are extremely valuable biodiversity resources within this larger area of great biodiversity. Eglin Air Force Base (EAFB) is essential for global conservation of steepheads because this vast area holds the greatest number under single ownership. Steepheads are significantly threatened by feral swine rooting damage. A decade-long investigation of EAFB's steepheads assessed the following: (1) severity of swine damage to steepheads, (2) changing levels of swine control on swine population and damage, (3) changing climatic conditions on damage, (4) changing military land use on damage (5) bioeconomics of damage. Swine damage to 21 EAFB steepheads was assessed 5 times over 10 years. Swine populations were indexed 8 times. Damage and population estimates were related to control effort, military land use, and climate variables to assess influences on damage levels. Monetary values were applied to estimates of total damage across all steepheads. Full control staffing rapidly reduced feral swine abundance and steephead damage. Reduced control staffing and reduced access from increased military activities allowed population rebound and increased damage. Drought possibly increased susceptibility to damage because steepheads provide a steady water source despite climatic circumstance. Estimated damage values across EAFB's steepheads (excluding other resources damaged) was 1.5-11.3 times more than annual control costs. Effective swine control greatly reduces steephead damage. Technological advances may overcome access issues from changing land use. Swine control is a cost-effective steephead conservation approach.
\end{abstract}

Keywords Animal damage management $\cdot$ Biodiversity $\cdot$ Bioeconomics $\cdot$ Ecological sampling $\cdot$ Invasive species $\cdot$ Sus scrofa

Communicated by Xiaoli Shen.

This article belongs to the Topical Collection: Invasive species

Dennis Teague: Deceased. 


\section{Introduction}

Biodiversity hotspots, regions of great biodiversity richness, are irregularly distributed across our planet, and often are emphasized for conservation, particularly when characterized by concentrations of endemism (Noss et al. 2015). The Florida panhandle is one of North America's significant biodiversity hotspots (Blaustein 2008; Means 2011; Stein et al. 2000; Wolfe et al. 1988), due in part to its warm wet (mesic) climate, continental connection (not a peninsula or an island), both Gulf Coastal Plain and Atlantic Coastal Plain influences, and river valleys connecting far inland (FNAI 2010; Means 2011). It has been identified as one of the top three biodiversity hotspots for U.S. and Canada (Noss et al. 2015). Steephead ravines, on a global scale, are unusual geological features that rarely occur outside of a narrow latitudinal band in the Florida panhandle (Means 2011). Because of the unique habitats they form, steephead ravines are extremely valuable biodiversity resources within this larger area of great biodiversity (Blaustein 2008; Means 2011).

Steephead ravines result from geologic circumstances where rainwater percolating through sandy upland soils is blocked by an impermeable layer (usually clays) (FNAI 2010). Groundwater sapping occurs laterally at this layer until the groundwater emerges as seeps and springs and erodes the sand to create a steep-walled amphitheater, U-shaped in cross-section. Thus, steepheads are substantially different in origin, form, and stream discharge from the usually dry V-shaped ravines created when rainwater erodes the ground surface (Enge 1998; FNAI 2010; Means 2011). Steephead ravines erode headward primarily from the valley bottom (Enge 1998; FNAI 2010; Means 1991; Sellards and Gunter 1918; Sharp 1938; Wolfe et al. 1988), producing steephead stream gradients much shallower than other streams in similar terrain (FNAI 2010). At the ravine edge, steephead walls slope steeply (up to $45^{\circ}$ ) and the ravine floor can be $35 \mathrm{~m}$ below the surrounding terrain (Enge 1998; FNAI 2010; Means 2011).

Steepheads have greater humidity and cooler temperatures than the surrounding terrain. The steep valley walls and the groundwater seepage stream buffer temperature and humidity extremes to produce relatively constant environments (Means 2011). Thus, steephead ravines support a diverse array of plants and animals that probably would not survive in this region of Florida otherwise, and the progression of plant life down the steephead slopes accentuates the biodiversity (Blaustein 2008; Means 2011). These forests blend rare plants, coastal plain species, and species more typically found farther north. (Platt and Shwartz 1990; Hubbell et al. 1956). Many (40+) rare plant and animal species are found in steepheads, with some found exclusively in steephead ravines and their streams (Enge 1998; FNAI 2010; Means 1981, 1991), including the following brief list of examples: Ashe's magnolia (Magnolia ashei), Florida flame azalea (Rhododendron austrinum), Baltzell's sedge (Carex baltzellii), silky camellia (Stewartia malacodendron), green violet (Hybanthus concolor), southern dusky salamander, (Desmognathus auriculatus), and Florida bog frog (Rana okaloosae) (Da Silva Neto et al. 2014; Enge 1998; FNAI 2010; Means 1981, 1991).

Steepheads are sensitive to disturbances that promote erosion. As such, rooting damage by feral swine (Sus scrofa) is a common type of disturbance that threatens steephead habitats (FNAI 2010; Kindell et al. 1997; Means 2011). Feral swine are one of the world's most destructive invasive species, infamous for their damage to native plant species, animal species, and habitats, as well as archaeological sites (Choquenot et al. 1996; Engeman et al. 2007, 2017; Seward et al. 2004; TWS 2011; USDA 1999; 2016). They also harbor diseases transmittable to wildlife, livestock, or humans (Corn et al. 2005; TWS 2011; USDA 2016; 
Wyckoff et al. 2009). Thus, the species is included among the 100 "World's Worst" invaders by the IUCN Invasive Species Specialist Group (e.g. Lowe et al. 2004). Their presence in North America dates to introductions by early European explorers beginning with the Spanish explorer de Soto who in 1539 introduced them to Florida. Many intentional and accidental introductions have followed (Belden and Frankenberger 1977; Mayer and Brisbin 2008; Towne and Wentworth 1950) and now invasive populations of feral swine exist in at least 35 of the 50 states in the USA (USDA 2016). Exacerbating the problem, the reproductive fitness of feral swine matches their destructive capabilities, as the species has the greatest reproductive potential of all North American large wild mammals (West et al. 2009; Wood and Barrett 1979).

Feral swine, sometimes described as "nature's rototillers" (Musante and Hall 2011; Senter 2003), pose a destructive threat to many vulnerable habitats. Feral swine have been implicated by some as the single greatest vertebrate modifier of natural plant communities (Bratton 1977; Wood and Barrett 1979). Rooting may damage plant population age structures, deter succession, and change species composition (Bratton 1977; Cole et al. 2012; Boughton and Boughton 2014; Groot Bruinderink and Hazebroek 1996), along with increasing invasibility by exotic plant species (Cushman et al. 2004; Kotanen 1995). Habitat damage by feral swine is particularly pronounced in wet environments where plant communities and soils may be more sensitive to disturbance (Choquenot et al. 1996; Engeman et al. 2007; West et al. 2009; USDA/APHIS 2015).

Eglin Air Force Base (referred to as "EAFB" henceforth) is especially important in the global conservation of steepheads because it has the greatest number and highest density of steepheads under a single ownership (FNAI 2010). Feral swine have been identified and prioritized as EAFB's most problematic invasive animal species threatening natural ecosystems (SAIC 2010), especially for EAFB's steephead ravines (FNAI 2010; Kindell et al. 1997; Means 2011; Means and Travis 2007; SAIC 2010). Not surprisingly, feral swine control was advocated and implemented for protection of steepheads and other wetlands (Engeman et al. 2007; Kindell et al. 1997; SAIC 2010).

We carried out a decade-long investigation at EAFB to accomplish the following: (1) assess the extent of swine damage to wetlands on steephead ravines valley floors, (2) assess whether changing levels of swine control affect swine population and damage levels, (3) assess changing climatic conditions on swine damage levels, (4) assess changing military land use patterns on swine damage levels, (5) assess swine damage from a bioeconomic perspective.

\section{Methods}

\section{Study area and steephead characteristics}

EAFB covers a large area, approaching the size of the smallest U.S. state, Rhode Island $(187,780 \mathrm{ha}$, ca $82 \mathrm{~km} \mathrm{E-W}$ and $31 \mathrm{~km} \mathrm{~N}-\mathrm{S})$. Approximately $86 \%$ of EAFB is forested, $12 \%$ dedicated solely to military activities (i.e., airfields, cleared test ranges, test sites, rights-of-way, and administrative areas), and the remaining $2 \%$ is comprised of water, marshes and barrier island (Kindell et al. 1997). EAFB lands are used extensively for recreation, including sport hunting for a variety of bird and mammal species. The Air Force is responsible for protecting and managing natural and cultural resources within its stewardship under various State and Federal laws and regulations. EAFB is recognized as a 
significant conservation area in a region regarded as a biodiversity hotspot (Blaustein 2008; Means 2011; Stein et al. 2000; Stein et al. 2008). Approximately half of EAFB may be hunted during various seasons, with opportunities to hunt feral swine during seasons running from mid-October through mid-February. Swine are considered feral animals on EAFB and are not subject to bag limits (U.S. Air Force 2002), although relatively few swine are removed through recreational hunting.

The terrain where EAFB's steephead ravines are found typically is gently rolling sandhill habitat with a xeric longleaf pine-scrub oak community (FNAI 2010; Means 1981). The plant communities within steephead ravines are highly diverse. Dry forests typify upper-slopes of steepheads, moist hardwood forests exemplify mid and lower slopes, and the lowest slope segment typically holds an evergreen shrub zone (FNAI 2010; Means 1981). Seepage-fed wetlands are on valley floors (FNAI 2010; Means 1981). A variety of rare plants are found on steephead slopes and wetlands (FNAI 2010; Means 1981; Wolfe et al. 1988).

\section{Study sites and damage measurements}

EAFB probably holds at least 190 steephead ravines, although the exact total is not known for this large and wild area. We studied 21 steephead ravines, which were randomly chosen and spatially stratified across EAFB. Within each studied steephead ravine, a permanent baseline was established on the valley floor at its center by first choosing an azimuth running directly down the steephead's center, towards the direction of the main stream. The baseline in each steephead was marked by placing a permanent pole to define its start point where groundwater first exits the headwall slope (Fig. 1). Up to 10 perpendicular transect lines were positioned every $5 \mathrm{~m}$ along the baseline with transects alternating right or left of the baseline (initial side randomly assigned) and ending at the base of the steephead slope (Fig. 1). A random number from 1 to 5 was chosen to select the distance (m) from the start of the baseline for placing the first transect. The start and end points of each perpendicular transect were also marked with permanent poles. Establishment of transects was discontinued when the main stream channel had been reached or the steephead slope significantly decreased to where monitoring personnel believed they had exited the steephead. Steepheads were sampled in 2004, 2005, 2006, 2009, and 2013.

At each sampling occasion, a measuring tape was stretched from the baseline to the base of the slope between the permanent poles (Fig. 2). A $2 \mathrm{~m}$ wide strip transect $1 \mathrm{~m}$ away and paralleling the measuring tape was used to observe the swine damage along each transect. Each strip transect ended $1 \mathrm{~m}$ before the baseline (Fig. 2). Conducting damage observations on strips $1 \mathrm{~m}$ from the transects minimized potential sampling errors caused by inadvertent disturbance from field observers. Within the strip transects, each damage patch was identified as "new" or "old." Swine damage was considered "new" if it appeared to be less than 3 months old as evidenced by a lack of leaf litter accumulation and vegetation growth within the damage area. For each strip transect, total areas of new and old damage were recorded.

\section{Damage estimation}

As identified in recent sampling research (Thomas et al. 2013), estimation of the proportion of each steephead's valley floor with damage was accomplished by first summing the total area of all strip transects within the steephead. The total area across all transects that 


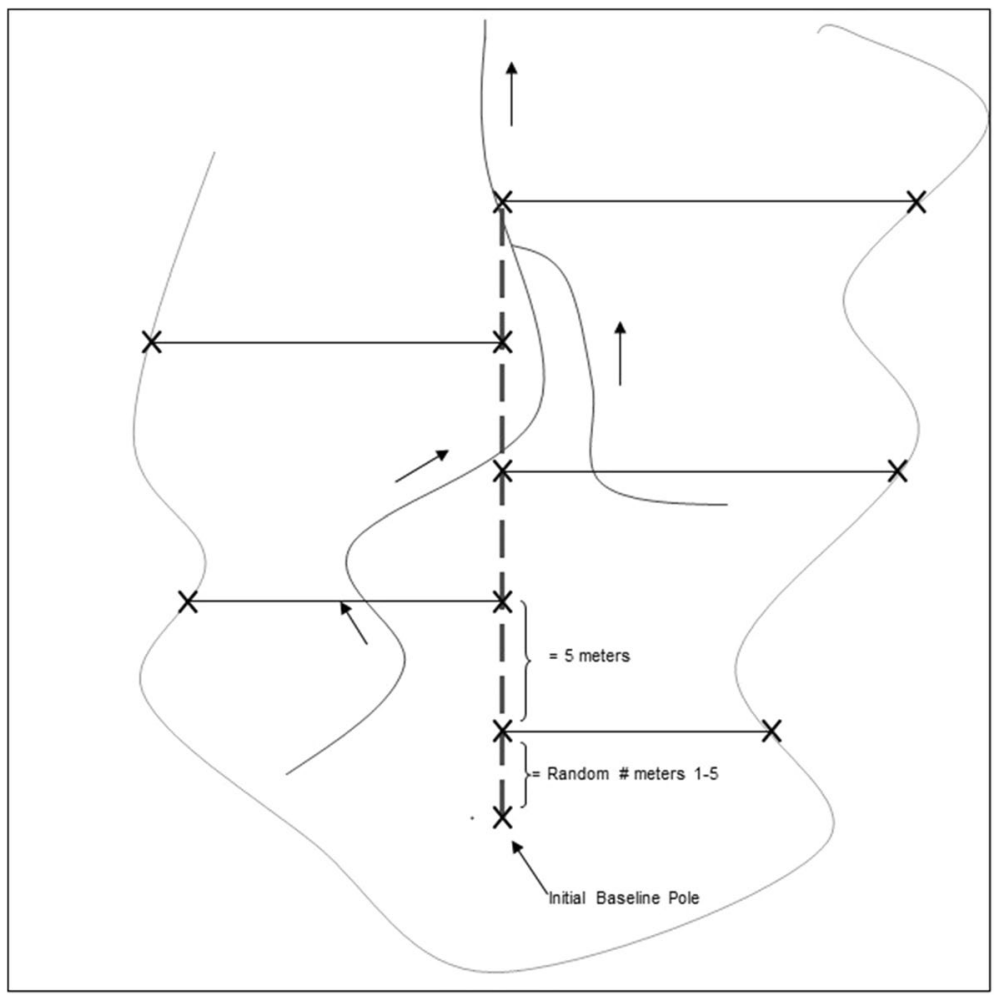

Fig. 1 Steephead ravine damage sampling design showing a baseline established down the steephead ravine center and perpendicular transects every $5 \mathrm{~m}$, alternating sides. The transects defined where strip transects were applied for measuring damage

was under water in the steephead stream was subtracted from this total to define the total area of terrestrial steephead valley floor habitat sampled. Total area of all damage was the sum of new and old damage areas across all strip transects. The proportion of steephead valley bottom with new and all damage by feral swine was estimated by dividing the sum of new and all damage areas by total area of transects combined (Thomas et al. 2013).

Given the estimated proportions for all damage and new damage for each steephead, we also estimated the area of each steephead's valley floor with damage. This required an estimate of each steephead's valley floor area. Due to an inability to determine valley floor areas from GIS data, and the impracticalities for on-the-ground measurements, valley floor areas were estimated as a series of adjacent trapezoids defined by the lengths of observation transects and the $5 \mathrm{~m}$ inter-transect spacing. Then, the total areas of all damage and all new damage across the entire steephead valley bottom on a given sampling occasion were estimated as the calculated damage proportion from the transects, as above, multiplied by the estimated area of the steephead valley bottom.

Further, we used our estimates of valley floor areas and damage proportions to also estimate the total land area across all EAFB's steephead valley floors with damage each year of measurement. We multiplied the mean valley floor area from our sampled steepheads by 190 , the minimum number of steephead ravines at EAFB, to conservatively estimate the combined valley floor area over all EAFB's steephead ravines. Then, for each year we 


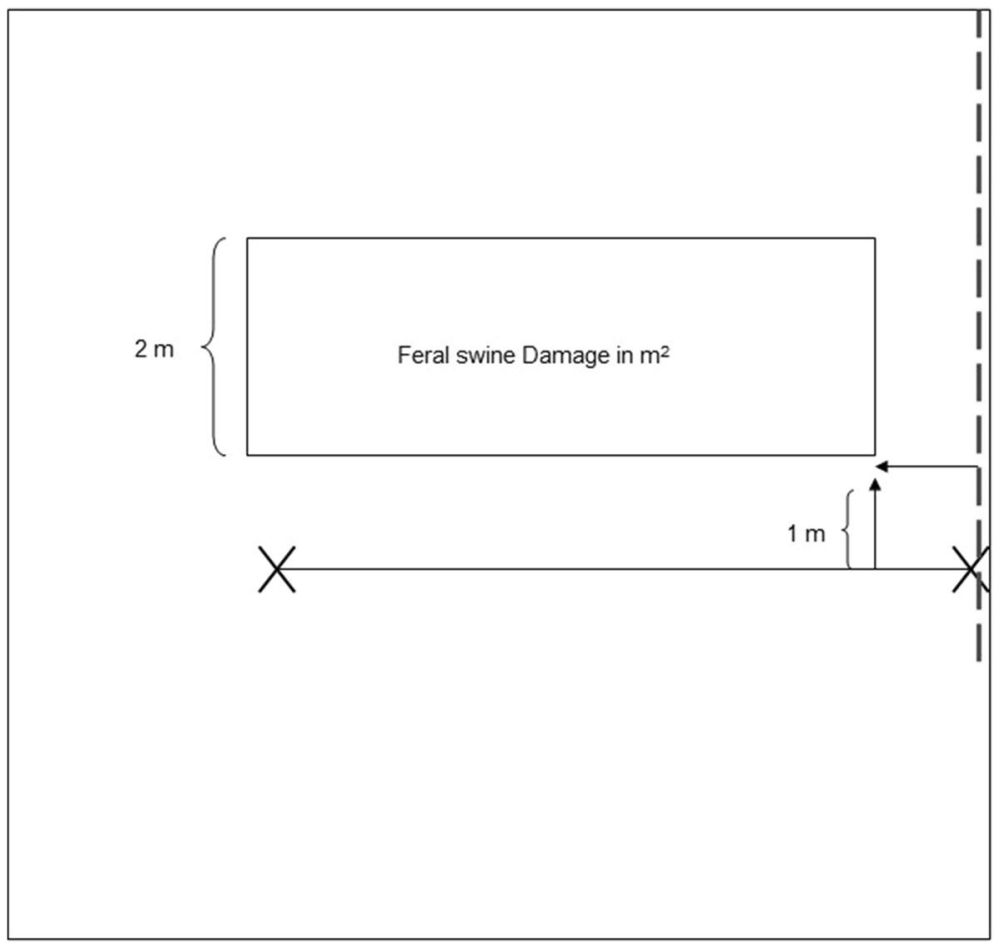

Fig. 2 Relationship of strip transects for measuring damage to transects established every $5 \mathrm{~m}$ perpendicular to baseline running down the steephead ravine center

multiplied the mean damage proportions from our valley floor samples by the estimated total valley floor area for EAFB to estimate the total valley floor area damaged across EAFB's steephead ravines.

\section{Swine population indices}

Feral swine were monitored using a passive tracking index (PTI) methodology customized for EAFB's logistics and landscape (Engeman and Allen 2000; Engeman et al. 2007). Briefly, data collection for such an index is most efficient if observation stations can be placed to intercept predicted daily activity of animals (e.g., Allen and Engeman 2015; Engeman 2005; Engeman et al. 2013). Roads and tracks through native terrain offer many animal species convenient travel routes, making them prime locations to place observation stations, and this has often proven the case for monitoring feral swine in various places in the world including Florida (e.g., Engeman et al. 2007, 2013).

The swine population was monitored as a whole for the entire of the base. To this end, tracking plots located randomly along roads throughout EAFB provided an efficient design for sampling on this large scale (Pearson and Ruggiero 2003; Engeman et al. 2007). Plots were $1.6 \mathrm{~km}$ long with at least $1.6 \mathrm{~km}$ between plots. Plot surfaces were smoothed for reading tracks by dragging $2 \mathrm{~m}$-wide chain loops behind a pickup truck and inspected the following day with the number of swine intrusions (number of sets of tracks) recorded. Daily counts of passive (no use of attractants or drives) tracking plot intrusions were produced 
as feral swine intercepted plots during their normal daily activities. The freshly smoothed, typically sandy, soil allowed easy detection of swine tracks. The process of preparing the tracking surfaces and recording numbers of swine intrusions was repeated for three consecutive days. The same plot locations were used each year for sampling (Engeman 2005; Ryan and Heywood 2003). PTI data were collected annually from 2003 to 2007, and also in 2009, 2011, 2015.

PTIs for feral swine were calculated by using formulae from the indexing paradigm of Engeman (2005), which has been specifically applied to tracking plot data for assessing feral swine abundance in a variety of studies (e.g., Engeman et al. 2007, 2013). All calculations followed the procedures and results in Engeman (2005) and Shulman et al. (2016).

\section{Feral swine removal}

Feral swine removal was initiated at EAFB in fall 2003 and has continued to the present by agreement with U.S. Department of Agriculture/Wildlife Services (WS), the Federal agency responsible for managing conflicts with wildlife (USDA/APHIS et al. 1997). WS uses only approved and humane methods to euthanize animals, which conform to guidelines laid by the American Veterinary Medical Association Panel on Euthanasia (AVMA 2013) and set forth as agency policy in USDA/APHIS/WS Directive 2.505. Swine were primarily removed by capture in pen traps and euthanized, with some removed by sharpshooting.

Control intensity varied across years with staffing. Full control staffing was two full time specialists tasked with swine control. However, staff actually available for full-time control varied between 1 and 2 people, referred to here as half and full staffing. Years 2004-2010 were fully staffed and years 2011-2015 half-staffed. Control efforts shifted geographically according to need and area closures due to military activities ("Discussed" section).

Feral swine were also removed through recreational hunting (U.S. Air Force 2002), an activity open to the public for decades. Hunter take was recorded at game check stations for hunting units, although hunter numbers were not monitored. During this study, areas open to public recreational hunting changed according to military activities, as did regulations on methods. Because of these dynamics and that recreational hunters were excluded from closed portions of EAFB (but operational control might take place), we expected inconsistent hunter take of swine, with unpredictable impacts on damage.

\section{Precipitation data}

The natural resources at EAFB most threatened by swine-inflicted damage are wetlands. We were interested whether feral swine attraction to steepheads was related to how wet or dry the climate was each year. For example, during drought steepheads might be particularly attractive to feral swine, because steephead streams run perennially through all levels of precipitation. Thus, we evaluated whether damage was related to changing moisture levels. To generally classify each year as dry/drought, normal, or wet, we applied the Evaporative Demand Drought Index (EDDI) (Lukas et al. 2017). Moisture status at the terrestrial surface is balanced between gains from precipitation and losses from evapotranspiration. The EDDI is an index that reflects the "unusualness" of existing conditions compared to the historical range in daily evaporative demand aggregated over a specified time frame (i.e., the "thirst" of the atmosphere, which drives soil and vegetation drying) (Lukas et al. 2017). EDDI is calculated from atmospheric observations near the land surface including: 
temperature, humidity, windspeed, and solar radiation. EDDI is not sensitive to land-cover type, making it equally applicable to all regions (Lukas et al. 2017). EDDI data from 1980 to present are available from the EDDI homepage provided by the National Oceanic and Atmospheric Administration (https://www.esrl.noaa.gov/psd/eddi/, accessed 26 Jan 2018) (Fig. 3).

\section{Military activity levels}

As the largest U.S. Air Force base, EAFB has always had considerable military activity. However, in 2005 U.S. Congress passed Base Re-Alignment and Closure (BRAC) legislation, which required the military to downsize from cold-war era "super-sized" military presence to be more compact and lean. BRAC closed smaller, less necessary military installations by moving their tenants to other bases. Beginning in 2011, BRAC greatly increased on-the-ground mission tempo to EAFB including new, different, and more testing and training requirements. We categorized each year's military activity level as "standard" for pre-BRAC activity or "heightened" for post-BRAC activity, because increased military activity changed base land use practices, directly affecting swine removal capabilities by restricting where and when control operations could take place. Increased military activity limited access into portions of EAFB that formerly had long term adequate feral swine control. During the time military activities increased, control staff vacancies further reduced capacity for feral swine control.

\section{Data analyses}

Two primary damage variables were each analyzed for both total damage and new damage: the amount measured across sample transects within each steephead, and the proportion of sampled steephead area with damage. The same area of measured damage represented different impacts at different steepheads based on the proportion of steephead area damaged. Thus, for analytical purposes we considered the proportion of area damaged (for both total damage and new damage) as equally important for analyses as the amount of damage measured on the transects at each steephead on each occasion. We analyzed these four

Fig. 3 Evaporative Demand Drought Index (EDDI) Eglin Air Force Base (EAFB) from 1980 to 2017. Spatial resolution for the data was $1 / 8$ th degree in latitude and longitude (approximately $12 \mathrm{~km}$ ). Our study period from 2003 to 2015 had both the wettest year (2003) and the driest years (2011)
12 month EDDI ending in December(1980-2017): for Eglin AFB, FL

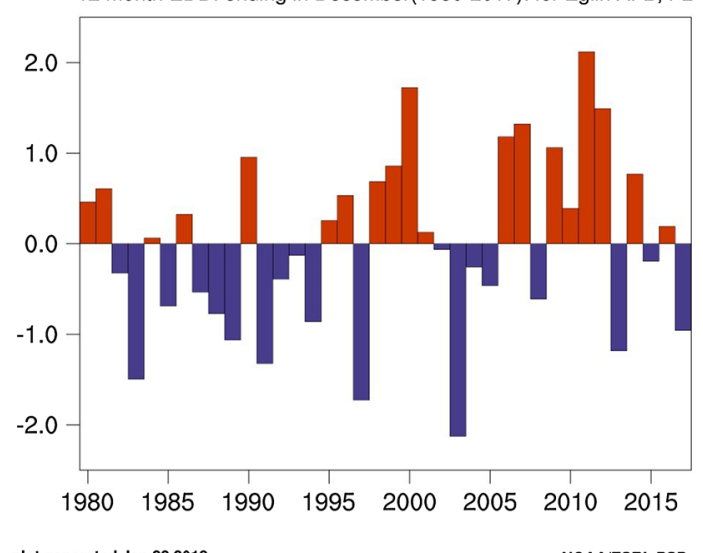


magnitude and proportion variables as one-factor repeated measures ANOVAs and used linear contrasts to make comparisons of particular interest among years to investigate factors potentially influencing damage levels, described below.

A variety of dynamically changing factors potentially affected the propensity for feral swine to damage steephead ravines (Table 1). Steephead damage sampling occurred annually during the first 3 years of study, with multi-year spans between sampling occasions thereafter. Comparisons of damage among years were orchestrated to obtain insights on factors potentially influencing damage levels.

Operational removal of feral swine (year-round professional swine control) initiated in fall 2003 and has continued to the present. Thus, the first 3 years of damage sampling (2004-2006) coincided with the first three full years of operational control of feral swine. During these 3 years there was full staffing of control personnel (constant effort) and essentially the same level of military activities "as usual" on EAFB (standard activity level). The feral swine population was monitored using the PTI beginning in 2003, before control was initiated, and continued through each of these 3 years. However, the climate varied among these years. The first 2 years $(2004,2005)$ of damage sampling were wet years, with the third year (2006) the first of a two-year drought. If climatic conditions had no effect on the propensity for feral swine to enter and damage steephead ravines, then we would expect an annually decreasing population due to control with concomitantly decreasing damage levels. Alternatively, steephead ravines might offer feral swine refuges and food sources during drought conditions, whereby even a decreased population might have an increased or concentrated usage and damage impact. Damage comparisons among the first 3 years were examined for climatic effects superseding cumulative impacts from control, given static control effort and military activity.

Table 1 Variables potentially influencing feral swine damage to steephead ravines (SHR) at Eglin Air Force Base, Florida, and years with damage measurements

\begin{tabular}{|c|c|c|c|c|c|}
\hline Year & $\begin{array}{l}\text { SHR dam- } \\
\text { age assess }\end{array}$ & Climate/EDDI & Control staffing & Military activity & $\begin{array}{l}\text { Swine popula- } \\
\text { tion monitor- } \\
\text { ing }\end{array}$ \\
\hline
\end{tabular}

\begin{tabular}{llllll}
\hline 2003 Jan-Sep & No & Wet (EW4) & Pre-control & Standard & Standard \\
2003 Oct-Dec & & Wet (EW2) & Full & Yes \\
2004 & Yes & Wet (EW0) & Full & Standard & Yes \\
2005 & Yes & Wet (EW0) & Full & Standard & Yes \\
2006 & Yes & Drought (ED1) & Full & Standard & Yes \\
2007 & No & Drought (ED1) & Full & Standard & Yes \\
2008 & No & Wet (EW1) & Full & Standard & No \\
2009 & Yes & Drought (ED1) & Full & Standard & Yes \\
2010 & No & Drought (ED0) & Full & Standard & No \\
2011 & No & Drought (ED4) & Half & Heighten & Yes \\
2012 & No & Drought (ED2) & Half & Heighten & No \\
2013 & Yes & Wet (EW1) & Half & Heighten & No \\
2014 & No & Drought (ED0) & Half & Heighten & No \\
2015 & No & Wet (EW0) & Half & Heighten & Yes \\
\hline
\end{tabular}

EW and ED are percentiles for wetness or dryness measured by Evaporative Demand Drought Index (EDDI). EW0 and ED0 are 30th and 70th percentiles. EW1 and ED1 connote 20th and 80th percentiles. EW2 and ED2 mark 10th and 90th percentiles. EW3 and ED3 are 5th and 95th percentiles, and EW4 and ED4 are 2nd and 98th percentiles. Italised years with SHR damage measurements 
The next 2 years when damage measurements were made (2009 and 2013) differed greatly in control staffing and military activity. There was full swine control staffing and standard military activity in 2009, whereas 2013 had only half staffing for control and heightened military activities with greater temporal and geographic restrictions on control activities (Table 1). These 2 years also differed climatically, with 2009 a drought year and 2013 a wet year (Table 1). Comparing 2009 to 2013 offered the greatest differences in circumstances among any two consecutive damage sampling occasions.

Comparing damage between 2009 with the previous sampling occasion, 2006, would examine stability or changes in trends, as both were drought years with full control staffing and standard military activity. Corresponding swine population levels could be assessed using the results from PTI monitoring from 2006, 2007, and 2009. Comparing 2005 to 2013 evaluated during climatically comparable years the combined impacts of reducing control capacity and restricting where and when that reduced capacity could be applied. The 2013 relative swine population level was probably best inferred as between the levels observed in 2011 and 2015 when population monitoring took place. Relative population levels observed in 2003 (pre-control) and 2004 (early control) compared with levels observed in 2011 and 2015 would juxtapose pre-control abundance with multi-year circumstances of reduced control staffing and access favoring population recovery.

A comparison between swine damage observed in 2004, shortly after initiation of control when the population was presumed to remain near its peak, with 2013, after control intensity and scope had been reduced for several years, would provide insight on damage that a potentially rebounding population could inflict (Table 1).

To further examine for relationships with damage, we calculated correlation coefficients between the four damage variables and the PTI abundance index, feral swine take by recreational hunters, and feral swine take by professional control experts. Because PTI was not measured in 2013, we interpolated between 2011 and 2015 assessments to approximate a value for 2013 .

New damage presents a "snapshot" perspective about ongoing damage. The proportion of steepheads with new damage indicates the rate at which damage is currently being initiated at steepheads across EAFB. Reductions or increases in the new damage prevalence across EAFB provide insight towards damage trends and where to focus control efforts. We analyzed a dichotomous variable, whether or not new damage was found for each sampling occasion at each steephead. We compared prevalence of new damage to steepheads among years using Cochran's Q test.

\section{Economic assessment of damage}

An economic perspective examining swine damage costs of steephead ravines provides useful information for documenting the need and validating the application of fiscal and human resources for protecting EAFB's natural treasures. Economically assessing damage requires placing a value on damage, which has been carried out for a variety of wetlands in Florida using expenditure data from Environmental Protection Agency (EPA) permitted mitigation projects (Engeman et al. 2004, 2016b; King 1998). These data provide an empirical, defensible, logical valuation for damaged wetland habitats, including previously at EAFB for feral swine damage to seepage slopes (Engeman et al. 2007). These government-permitted expenditure data are empirical demonstrations of willingness-to-pay value, and are available for many wetland habitat types. In particular, King (1998) summarized dollar values per-unit-area expended in restoration efforts for various wetland habitat types. 
The values represent amounts that environmental regulators authorized permit applicants to spend attempting to restore lost wetland values and services (King 1998). Combined with adjustments for annual inflation rates (Zerbe and Dively 1994), these figures allow credible habitat valuations to be calculated. Because steephead ravines' wetland habitats are rare, they are not expressly enumerated among categories provided by King (1998). Thus, as for previous swine damage valuations for unique and rare wetlands in Florida (e.g., Engeman et al. 2007, 2016b), we applied the median figure from King (1998) over freshwater wetland types (excluding prairie potholes) as an empirical "willingness to pay" value for restoration. The restoration cost estimate at the time of our final damage assessment in 2013, and after adjusting for 3\% annual inflation rate since King (1998) presented the values, was $\$ 491,775 /$ ha (King 1998; Zerbe and Dively 1994).

\section{Results}

The proportion of damage observed across sampled steephead ravines varied among sites and years from 0 to $94 \%$, but usually $<10 \%$. Despite this variability, important general aspects of damage factors were evident.

Continuous application of consistent feral swine control during unchanging military land use patterns was expected to show a decreasing swine PTI, and logically be accompanied by decreasing damage. In 2004, the PTI (Table 2) dropped substantially from pre-control in $2003(\mathrm{Z}=1.951, \mathrm{p}=0.051)$. The decline continued in $2005(\mathrm{Z}=2.739, \mathrm{p}=0.006)$, and reached its minimum in 2006, which was not statistically distinguishable from 2005 $(\mathrm{Z}=0.764, \mathrm{p}=0.445)$. Damage was not assessed in steephead ravines prior to initiation of feral swine control. Thus, the first damage assessment (in 2004) followed nearly a year of swine control. The four damage variables (total amount of damage, total amount of new damage, proportion damaged, and proportion with new damage), like the PTI, each decreased considerably from 2004 to 2005, but unlike the PTI, each rose to an intermediate value in 2006, a drought year (Table 2). Differences between 2004 and 2005 were indicated for total damage $\left(\mathrm{F}_{1,80}=3.30, \mathrm{p}=0.073\right)$ and amount of new damage $\left(\mathrm{F}_{1,80}=4.73\right.$, $\mathrm{p}=0.033$ ). However, neither comparison of proportions for all damage or new damage indicated differences between 2004 and $2005\left(\mathrm{~F}_{1,80}<1.96, \mathrm{p}>0.165\right)$. Although the four damage variables rose between 2005 and 2006, no differences were detected $\left(\mathrm{F}_{1,80}<0.60\right.$, $\mathrm{p}>0.442$ ).

In 2007 the PTI increased from its minimum in $2006(\mathrm{Z}=3.986, \mathrm{p}<0.001$; Table 2), but remained less than in 2004, and remained nearly the same level when next sampled in 2009 $(\mathrm{Z}=0.161, \mathrm{p}=0.872$; Table 2). Both 2006 and 2009 were drought years with full control staffing and standard military activity. As expected when a population increase is indicated, the four damage variables also appeared to increase from 2006 to 2009 (Table 2), but no damage variable was statistically distinguishable from its value in $2006\left(\mathrm{~F}_{1,80}<1.64\right.$, $\mathrm{p}>0.205)$.

In 2013, the third consecutive year when heightened military activity greatly restricted access for control, and also the third consecutive year of half control staffing, damage increased considerably from 2009 for all damage variables, reaching the highest levels observed during the study $\left(\mathrm{F}_{1,80}>20.06, \mathrm{p}<0.0001\right.$; Table 2$)$. Since 2005 and 2013 were climatically comparable years, comparing their damage provided insights with minimal climate influences about the combined impacts of reducing control capacity and restricting where and when control could be applied. Strong differences were found as all four 


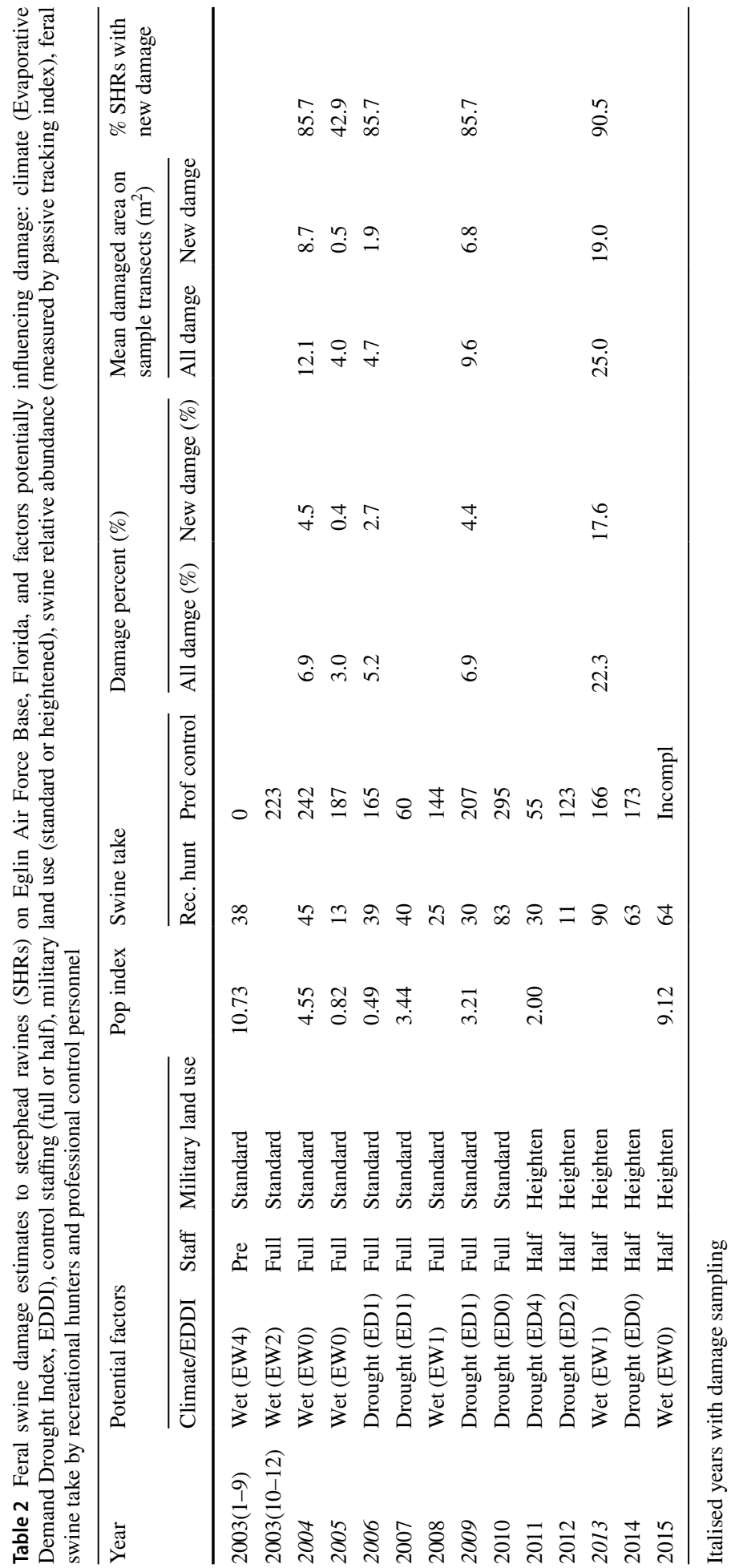


variables were considerably larger in $2013\left(\mathrm{~F}_{1,80}>22.38, \mathrm{p}<0.0001\right.$; Table 2$)$. Comparing 2004 and 2013 assessed swine damage shortly after initiation of control to damage from a potentially rebounding population after control intensity and breadth had been reduced for several years, and again found all four variables to be substantially larger in $2013\left(\mathrm{~F}_{1,80}>7.27, \mathrm{p}<0.009\right.$; Table 2$)$. PTI sampling was not conducted in 2013. However, PTI sampling was conducted in 2011 where a decline from 2009 was indicated but not statistically detected $(Z=1.530, \mathrm{p}<0.126)$, and in 2015 where it rose substantially from 2011 $(Z=2.783, p=0.005)$ to a value nearly as high and not statistically distinguishable from pre-control levels in $2003(\mathrm{Z}=0.465, \mathrm{p}=0.642$; Table 2).

The proportion of steepheads having new damage was in a narrow, but high, range from 85.7 to $90.5 \%$ for four of 5 years of sampling (Table 2). The exception was 2005 with a $42.9 \%$ new damage prevalence, half that seen in the other four sample years, and borne out with Cochran's Q test $\left(X_{4}^{2}=35.4, p<0.0001\right)$.

Correlating damage variables with potential influencing variables produced both expected and unexpected results, even though only the strongest relationships reached statistically detectable levels with just 5 years of damage data (Table 3). As expected, the PTI abundance index was positively correlated with damage, but only the high correlations with the measured amounts of all damage and new damage were statistically detectable, even though correlations with proportion damaged variables were $>0.77$ (Table 3). What, on the surface, seemed surprising was highly positively correlations between feral swine take by recreational hunters with all four damage variables $(r>0.93, p<0.03$, Table 3 ) (see Discussion for possible explanations). Feral swine removed by control professionals had near-zero negative correlations with amounts of damage and somewhat stronger negative correlations with proportion damaged variables, but all were not detectably different from zero (Table 3).

Table 4 presents the estimates of total steephead valley floor area damaged by feral swine across EAFB, along with associated estimates of value for the damage. Steephead valley floors are relatively small areas $\left(\bar{X}=760.5 \mathrm{~m}^{2}\right.$, $\left.\mathrm{se}=264.7 \mathrm{~m}^{2}\right)$, and the total area of steephead valley floors over EAFB's $\sim 190$ steepheads was 14.4 ha. Yet, the areas of feral swine damage when combined across EAFB represented considerable value (Table 4). These results may be conservative, because it is not known how many steephead ravines might be in EAFB's wildlands, and the applied valuation is also likely conservative in light of the rareness of steephead ravines as a wetland type compared to the general wetland

Table 3 Correlations ( $p$ value) between damage metrics and variables potentially influencing damage

\begin{tabular}{|c|c|c|c|c|}
\hline \multirow[t]{2}{*}{$\begin{array}{l}\text { Variables potentially influenc- } \\
\text { ing damage }\end{array}$} & \multicolumn{2}{|c|}{ Damage percent } & \multicolumn{2}{|c|}{$\begin{array}{l}\text { Mean combined damaged area } \\
\text { on sample transects }\end{array}$} \\
\hline & All damage & New damage & All damage & New damage \\
\hline Abundance (PTI) & $\begin{array}{l}0.90 \\
(p=0.04)\end{array}$ & $\begin{array}{l}0.92 \\
(p=0.03)\end{array}$ & $\begin{array}{l}0.77 \\
(p=0.13)\end{array}$ & $\begin{array}{l}0.79 \\
(\mathrm{p}=.11)\end{array}$ \\
\hline Recreational hunter take & $\begin{array}{l}0.94 \\
(p=0.02)\end{array}$ & $\begin{array}{l}0.93 \\
(p=0.03)\end{array}$ & $\begin{array}{l}0.96 \\
(p=0.01)\end{array}$ & $\begin{array}{l}0.96 \\
(p=0.01)\end{array}$ \\
\hline Take by professionals & $\begin{array}{l}-0.11 \\
(p=0.85)\end{array}$ & $\begin{array}{l}-0.07 \\
(\mathrm{p}=0.92)\end{array}$ & $\begin{array}{l}-0.35 \\
(\mathrm{p}=.56)\end{array}$ & $\begin{array}{l}-0.33 \\
(\mathrm{p}=0.59)\end{array}$ \\
\hline EDDI & $\begin{array}{l}-0.68 \\
(p=0.20)\end{array}$ & $\begin{array}{l}-0.63 \\
(p=0.25)\end{array}$ & $\begin{array}{l}-0.64 \\
(p=0.24)\end{array}$ & $\begin{array}{l}-0.63 \\
(\mathrm{p}=0.26)\end{array}$ \\
\hline
\end{tabular}


Table 4 Estimated proportions of feral swine damage to steephead ravines at Eglin Air Force Base (EAFB), estimated total area of damage across all EAFB steephead ravines, estimated value of combined damage area based on Environmental Protection Agency-permitted restoration costs adjusted for inflation to 2013 U.S. dollars (\$491,775/ha)

\begin{tabular}{lclc}
\hline Year & $\begin{array}{l}\text { Damage proportion } \\
(\%)\end{array}$ & $\begin{array}{l}\text { Combined area of damage across all } \\
\text { steephead valley floors (ha) }\end{array}$ & Damage value (USD) \\
\hline 2004 & 6.9 & 0.997 & $\$ 490,300$ \\
2005 & 3.0 & 0.433 & $\$ 212,939$ \\
2006 & 5.2 & 0.751 & $\$ 369,323$ \\
2009 & 6.9 & 0.997 & $\$ 490,300$ \\
2013 & 22.3 & 3.222 & $\$ 1,584,499$ \\
\hline
\end{tabular}

categories summarized for EPA-permitted restoration efforts (King 1998). The amounts expended on annual agreements for control were stable at $\sim \$ 140,000$ each year, making control expenditures each year a fraction of the value of swine damage.

\section{Discussion}

With the greatest concentration of steephead ravines under single management, EAFB is indispensable for conserving these ecological and evolutionary "islands" of unique habitats. Feral swine significantly threaten EAFB's steephead ravines, along with EAFB's other natural and cultural resources (FNAI 2010; Kindell et al. 1997; Means 2011; SAIC 2010). The high prevalence of new feral swine damage (86-91\% for four of five sample years) documented the pervasive threat feral swine pose to steephead ravines. New damage represents damage initiation, and demonstrates the potential for additional damage to ensue. Our objectives were to examine damage amounts to EAFB's steephead ravines valley floors, and factors influencing damage amounts.

Feral swine population abundance obviously influences damage levels, although other factors may affect attractiveness of steephead ravines to feral swine and result in damage levels that population abundance alone cannot account for. Typically, the greatest impacts from control are achieved shortly after initiation, because animals are most plentiful and naïve to control methods. Moreover, much control effort targeted areas closed to the public, meaning those animals had minimal prior human contact including no hunting. Control's immediate impact (Table 2) was the precipitous decrease in population abundance between pre-control (2003) and one year of control (2004), followed by further significant decline after a second year of control (2005), and bottoming after the third year of control (2006).

Damage results were less clear, especially since there was a year of control before damage was sampled, making comparisons to a pre-control baseline impossible. Like population, damage amounts (but not proportion) decreased between the first (2004) and second years of control (2005). Unlike population, all four damage variables increased in magnitude after the third control year (2006), which also was the first drought year sampled. However, these increases were not detectable statistically.

The next year sampled was 2009, another drought year with damage appearing to increase, although again not detected statistically. Confounding the effects of drought on damage, the PTI increased significantly from 2006 to 2007 and remained nearly the 
same in 2009 (Table 2). Thus, 2006 and 2009 may suggest some circumstantial evidence that steephead ravines might be more vulnerable to feral swine damage in drought years, but further study would be required to clarify the influences of drought on propensity for damage.

Finding recreational hunter take to be highly positively correlated with all four damage variables seemed counterintuitive and merits further consideration, because increasing feral swine removed by any means would be expected to help reduce damage. Recreational hunter take is probably highly influenced by hunter numbers in the field (hunter-days/hunting pressure) and population. Recreational hunter take also correlated well with PTI during damage sampling years $(\mathrm{r}=0.89,(\mathrm{p}=0.04)$. Besides contributing to more swine taken, greater hunting pressure may increase swine dispersal into more inaccessible areas and impenetrable habitats such as steephead ravines which are rugged, highly vegetated habitats, and physically difficult to enter and traverse for hunters, while offering feral swine refuges with abundant resources. Thus, hunting pressure, especially combined with higher populations, may lead to increased steephead damage. Another factor related to recreational hunting that leads to resource damage is that swine are often illegally released to initiate or augment populations for recreational hunting (e.g., Hernandez et al. 2018). There has been some indication of such illegal activities at EAFB as some of the swine captured during the course of this study had been ear-tagged or castrated.

Particularly important, damage increased substantially in 2013 after 3 consecutive years of both half control staffing and heightened military activities restricting access. Although not assessed in 2013, swine numbers appeared rapidly increasing, because the 2015 PTI was nearly as high and not statistically distinguishable from pre-control (2003). A population rebound under reduced control circumstances is not surprising because high feral swine reproductive potential can swiftly result in losing accrued control benefits. Moreover, while 2013 was a wet year, it followed an intense drought the previous two years. Once feral swine become conditioned to a valuable resource, they often heavily exploit it (Engeman et al. 2016a; Gates 2012; Mungal 2001). Thus, steephead ravines might have been highly valuable resources for swine wellbeing during the extended drought, conditioning them to heavily exploiting steepheads.

The financial agreement for control work remained fairly steady at $\sim \$ 140,000 /$ year through the study years. The estimated values of feral swine damage to all steephead ravines on EAFB combined were greater (usually much greater) than $\$ 140,000$ (Table 4). Because damage was not assessed prior to control initiation, a baseline isn't available to clearly define economic returns for control. One possibility would be to consider damage levels from 2004, because this sampling year was nearest in time to pre-control. However, this is also when greatest control impacts were likely to have taken place, making it an inappropriate pre-control damage surrogate. However, 2013 might be argued as a rough baseline for pre-control damage levels, especially with the PTI nearly the same as pre-control (2003) levels by 2015 (Table 2). Including 2013 losses to roughly estimate potential value of losses without control (yet conservative since control was still being conducted at lower levels), the estimated annual value of damage prevented ranged from $\$ 1,094,199$ to $\$ 1,371,561$, excellent returns on $\$ 140,000$ investments.

Essential for considering returns on EAFB's \$140,000 investment in swine control is that control protected all of EAFB's extensive natural and cultural resources from feral swine damage, not just steephead ravines, and included seepage slopes (Engeman et al. 2007), archaeological sites (Engeman et al. 2017), and critical endangered species habitats in pine flatwoods (Jones et al. 2017). Considering only damage values for steepheads is extremely conservative in concept, with returns considerably magnified if all resources 
protected are considered. Administrative decisions on management actions towards destructive invasive species are based on economic constraints in addition to need. The metric for success of management actions is typically measured in resource improvement, but concomitant application of monetary values to damage allows economic analyses to help evaluate and guide management actions.

Successful efforts over a large area like EAFB that reduce population and maintain the reduction require consistent, persistent, and pervasive control. Technology eventually could help overcome some obstacles to control with heightened military activity. Standard trapping methods require successive days with daytime access to monitor and tend traps. Various technological approaches could reduce the need for continuous access, thereby allowing trapping to be monitored remotely and continue during area closures. Automated feeders can deliver bait on a preset schedule and cameras can alert trappers when swine are in the trap by sending photos by cell phone. Trappers then remotely trigger trap doors by cell phone. Until cell phone coverage at EAFB increases this approach's utility is limited to areas with cell coverage.

Other technologies might overcome reduced access. Some area closures are lifted at night, and nighttime sharpshooting using high-quality FLIR rifle scopes could be effective. Another technology with potential for remotely controlling feral swine is a recently U.S. EPA-registered feral swine toxicant with accompanying target-specific delivery mechanism (Poché et al. in press). Another swine-specific toxicant bait/delivery system combination is being developed (Snow et al. 2017). Toxic baits could be effective with only intermittent visits to limited access areas. Additionally, aerial control can make rapid removal of many swine over large areas possible (Bodenchuk 2014), although arranging logistics for aerial gunning at military bases can be challenging.

Acknowledgements This research was supported by the intramural research programs of the U.S. Department of Agriculture and U.S. Department of Defense.

Funding This research did not receive any specific grant from funding agencies in the public, commercial, or not-for-profit sectors.

\section{Compliance with ethical standards}

Conflict of interest The authors declare that they have no conflict of interest.

\section{References}

Air Force US (2002) Integrated natural resources management plan. Eglin Air Force Base, Florida

Allen LR, Engeman RM (2015) Evaluating and validating abundance monitoring methods in absence of populations of known size. Environ Sci Pollut Res 22:2907-2915

AVMA (American Veterinary Medical Association) (2013) AVMA guidelines for the Euthanasia of animals, 2013th edn. American Veterinary Medical Association, Schaumburg, IL

Belden RC, Frankenberger WG (1977) Management of feral hogs in Florida-past, present, and future. In: Wood GW (ed) Research and management of wild hog populations. Clemson University, Clemson, pp 5-10

Blaustein RJ (2008) Biodiversity hotspot: the Florida panhandle. Bioscience 58(9):784-790

Bodenchuk MJ (2014) Method-specific costs of feral swine removal in a large meta-population: the Texas experience. In: Timm RM, O’Brien JM (eds) Proc 26th Vertebr Pest Conf Univ California, Davis, pp 269-271

Boughton EH, Boughton RK (2014) Modification by an invasive ecosystem engineer shifts a wet prairie to a monotypic stand. Biol Invasions 16:2105-2114 
Bratton SP (1977) Wild hogs in the United States_origin and nomenclature. In: Wood GW (ed) Research and management of wild hog populations. The Belle W. Baruch Forest Science Institute of Clemson University, Georgetown, SC, pp 1-4

Choquenot D, McIlroy J, Korn T (1996) Managing vertebrate pests: feral pigs. Bureau of Resource Sciences, Australian Government Publishing Service, Canberra

Cole RJ, Litton CM, Koontz MJ, Loch RK (2012) Vegetation recovery 16 years after feral pig removal from a wet Hawaiian forest. Biotropica 44:463-471

Corn JL, Cumbee JC, Chandler BA, Stallknecht DE, Fischer JR (2005) Implication of feral swine expansion: expansion of feral swine in the United States and potential implication for domestic swine. Feral swine subcommittee on brucellosis and pseudorabies. United States Animal Health Association, St. Joseph, MO, pp 295-297

Cushman JH, Tierney TA, Hinds JM (2004) Variable effects of feral pig disturbances on native and exotic plants in a California grassland. Ecol Appl 14:1746-1756

Da Silva Neto JG, Gorman TA, Bishop DC, Haas CA (2014) Population demographics of the Florida bog frog (Lithobates okaloosae). Southeast Nat 13:128-137

Enge KM (1998) Herpetofaunal drift-fence survey of steephead ravines in the Apalachicola and Ochlockonee river drainages. Florida Game and Fresh Water Fish Comm. Final Perf. Rep., Tallahassee

Engeman R (2005) Indexing principles and a widely applicable paradigm for indexing animal populations. Wildl Res 32:202-210

Engeman RM, Allen LR (2000) Overview of a passive tracking index for monitoring wild canids and associated species. Integr Pest Manag Rev 5:197-203

Engeman RM, Shwiff SA, Smith HT, Constantin BU (2004) Monetary valuation of rare species and imperiled habitats as a basis for economically evaluating conservation approaches. Endanger Species Update 21:66-73

Engeman RM, Stevens A, Allen J, Dunlap J, Daniel M, Teague D, Constantin BU (2007) Feral swine management for conservation of an imperiled wetland habitat: Florida's vanishing seepage slopes. Biol Conserv 134:440-446

Engeman RM, Massei G, Sage M, Gentle M (2013) Monitoring wild pig populations: a review of methods. Environ Sci Pollut Res 20:8077-8091

Engeman RM, Addison D, Griffin JC (2016a) Defending against disparate sea turtle nest predators: benefits to nesting success from eradicating invasive feral swine and caging nests from raccoons. Oryx 50(2):289-295

Engeman RM, Orzell SL, Felix RK Jr, Tillman EA, Killian G, Avery ML (2016b) Feral swine damage to globally imperiled wetland plant communities in a significant biodiversity hotspot in Florida. Biodivers Conserv 25:1879-1898

Engeman RM, Meyer JS, Allen JB (2017) Prevalence of feral swine disturbance at important archaeological sites over a large area in Florida. Sci Rep (Nat) 7:40287

FNAI (Florida Natural Areas Inventory) (2010) Guide to the natural communities of Florida. Florida Natural Areas Inventory and Florida Department of Natural Resources, Tallahassee, FL

Gates V (2012) Hog wild: feral pig population explodes in US. Chicago Tribune, June 22, 2012, Chicago

Groot Bruinderink GWTA, Hazebroek E (1996) Wild boar (Sus scrofa scrofa L.) rooting and forest regeneration on podzolic soils in the Netherlands. For Ecol Manag 88:71-80

Hernandez FA, Parker BM, Pylant CL, Smyser TJ, Piaggio AJ, Lance SL, Milleson MP, Austin JD, Wisely SM (2018) Invasion ecology of wild pigs (Sus scrofa) in Florida, USA: the role of humans in the expansion and colonization of an invasive wild ungulate. Biol Invasions 20:1865-1880

Hubbell TH, Laessle AM, Dickinson JC (1956) The Flint-Chattahoochee-Apalachicola region and its environments. Bull Fla State Mus 1:1-72

Jones KC, Gorman TA, Rincon BK, Allen J, Haas CA, Engeman RM (2017) Feral swine: a new threat to the remaining breeding wetlands of the endangered reticulated flatwoods salamander. Oryx 36:24. https:// doi.org/10.1017/S0030605316001253

Kindell CE, Herring BJ, Nordman C, Jensen J, Schotz AR, Chafin LG (1997) Natural community survey of Eglin Air Force Base, 1993-1996: final report. Florida Natural Areas Inventory, Tallahassee, Florida Natural Areas Inventory, Tallahassee

King D (1998) The dollar value of wetlands: trap set, bait taken, don't swallow. Natl Wetl Newsl 20:7-11

Kotanen PM (1995) Responses of vegetation to a changing regime of disturbance: effects of feral pigs in a Californian coastal prairie. Ecogr 18:190-199

Lowe S, Browne M, Boudjelas S, De Poorter M (2004) 100 of the world's worst invasive alien species a selection from the global invasive species database. Invasive Species Specialist Group, Auckland

Lukas J, Hobbins M, Rangwala I (2017) The EDDI user guide. NOAA Earth System Research Laboratory, Boulder, $\mathrm{CO}$ 
Mayer JJ, Brisbin IL (2008) Wild pigs in the United States: their history, comparative morphology, and current status. The University of Georgia Press, Athens, GA

Means DB (1981) Steepheads: Florida's little-known canyon lands. In: Enfo December issue. Florida Conservation Foundation, Winter Park, pp 1-4

Means DB (1991) Florida's steepheads: unique canyonlands. Fla Wildl 45(3):25-28

Means DB (2011) Final report: biodiversity dependent upon wetland ecosystems created by the surficial aquifer in Bay and Washington counties, Florida Coastal Plains Institute and Land Conservancy, Tallahassee

Means DB, Travis J (2007) Declines in ravine-inhabiting dusky salamanders of the southeastern US Coastal Plain. Southeast Nat 6(1):83-96

Mungal EC (2001) Exotics. In: Demarais S, Krausman PR (eds) Ecology and management of large mammals in North America. Prentice Hall, Upper Saddle River, NJ, pp 736-764

Musante A, Hall P (2011) Don't let New Hampshire go hog wild. N Hamps Wildl J. November/December: $8-11$

Noss RF, Platt WJ, Sorrie BA, Weakley AS, Means DB, Costanza J, Peet RK (2015) How global biodiversity hotspots may go unrecognized: lessons from the North American Coastal Plain. Divers Distrib 21:236-244

Pearson DE, Ruggiero LF (2003) Transect versus grid trapping arrangements for sampling small mammal communities. Wildl Soc Bull 31:454-459

Platt WJ, Schwartz MW (1990) Temperate hardwood forests. In: Myers RL, Ewel JJ (eds) Ecosystems of Florida. University of Central Florida Press, Orlando, pp 194-229

Poché RM, Poché D, Franckowiak G, Somers DJ, Briley LN, Tseveenjav B, Polyakova L (in press) Field evaluation of low-dose warfarin baits to control feral hogs (Sus scrofa) in North Texas. PloS One

Ryan DA, Heywood A (2003) Improving the precision of longitudinal ecological surveys using precisely defined observational units. Environmetrics 14:83-293

SAIC (Science Applications International Corporation) (2010) Final integrated natural resources management plan. Eglin Air Force Base, Florida

Sellards EH, Gunter H (1918) Geology between the Apalachicola and Ochlockonee rivers in Florida. Florida geological survey, 10th-11th Annual Report, pp 9-56

Senter J (2003) Live dunes and ghost forests: stability and change in the history of North Carolina's maritime forests. N C Hist Rev 80(3):334-371

Seward N, VerCauteren K, Witmer G, Engeman RM (2004) Feral swine impacts on agriculture and the environment. Sheep Goat Res J 19:34-40

Sharp HS (1938) Steepheads and spring-sapping-Holt and Niceville quadrangles, Florida. J Geomorphol $1: 249-298$

Shulman B, Grunwald G, Wagner B, Engeman RM (2016) Evaluation of estimation quality of a general paradigm for indexing animal abundance when observations are counts. Ecol Inf 32:194-201

Snow NP, Foster JA, Kinsey JC, Humphrys ST, Staples LD, Hewitt DG, VerCauteren KC (2017) Development of toxic bait to control invasive wild pigs and reduce damage. Wildl Soc Bull 41(2):256-263

Stein BA, Kutner LS, Adams JS (eds) (2000) Precious heritage: the status of biodiversity in the United States. Oxford University Press, New York

Stein BA, Scott C, Benton N (2008) Federal lands and endangered species: the role of military and other federal lands in sustaining biodiversity. Bioscience 58:339-347

Thomas J, Engeman RM, Tillman EA, Fischer JW, Orzell SL, Glueck DH, Felix RK Jr, Avery ML (2013) Optimizing line intercept sampling and estimation for feral swine damage levels in ecologically sensitive wetland plant communities. Environ Sci Pollut Res 20:1503-1510

Towne CW, Wentworth EN (1950) Pigs from cave to cornbelt. University of Oklahoma Press, Norman, OK

TWS (The Wildlife Society) (2011) Feral swine in North America. Final position statement. The Wildlife Society, Bethesda

USDA (U.S. Department of Agriculture) (1999) Wild pigs hidden danger for farmers and hunters, vol 620. Animal and Plant Health Inspection Services Information Bulletin, Washington, DC

USDA (U.S. Department of Agriculture) (2016) Feral swine: damages, disease threats, and other risks, vol 2195b. Animal and Plant Health Inspection Services Program Aid, Washington, DC

USDA/APHIS (U.S. Department of Agriculture/Animal and Plant Health Inspection Service) (2015) Final environmental impact statement feral swine damage management: a national approach. USDA/Animal and Plant Health Inspection Service, Washington, DC

USDA/APHIS (U.S. Department of Agriculture/Animal and Plant Health Inspection Service), U.S. Department of Agriculture/Forest Service and Department of Interior/Bureau of Land Management (1997) Animal damage control program final environmental impact statement (revised). USDA/Animal and Plant Health Inspection Service, Washington, DC 
West BC, Cooper AL, Armstrong JB (2009) Managing wild pigs: a technical guide. Human-Wildlife Interactions Monograph 1:1-55

Wolfe SH, Reidenauer JA, Means DB (1988) An ecological characterization of the Florida panhandle. U S Fish Wildl Serv Biol Rep 88(12):1-277

Wood GW, Barrett RH (1979) Status of wild pigs in the United States. Wildl Soc Bull 7:237-246

Wyckoff AC, Henke SE, Campbell TA, Hewitt DG, VerCauteren KC (2009) Feral swine contact with domestic swine: a serologic survey and assessment of potential for disease transmission. J Wildl Dis 45:422-429

Zerbe RO, Dively DD (1994) Benefit-cost analysis: in theory and practice. HarperCollins College Publishers, New York

Publisher's Note Springer Nature remains neutral with regard to jurisdictional claims in published maps and institutional affiliations.

\section{Affiliations}

Richard M. Engeman ${ }^{1} \cdot$ Erica Laine ${ }^{2} \cdot$ John Allen $^{3} \cdot$ Jeremy Preston $^{2}$. William Pizzolato ${ }^{2} \cdot$ Brett Williams $^{2} \cdot$ Amanda Stevens Kreider $^{2,4} \cdot$ Dennis Teague $^{2}$

Richard M. Engeman

richard.m.engeman@aphis.usda.gov

1 National Wildlife Research Center, 4101 LaPorte Ave, Fort Collins, CO 80521-2154, USA

2 Eglin AFB Natural Resources, 107 Hwy 85 N, Niceville, FL 32578, USA

3 USDA/APHIS/Wildlife Services, 2820 East University Ave, Gainesville, FL 32641, USA

4 Cardno, 65 Buckboard Rd, Tijeras, NM 87059, USA 